\title{
Macroeconomic Determinants of Indonesian Tourism Demand in Malaysia
}

\author{
Ahmad Feri Tanjung ${ }^{1}$, Fung-Thai Thien ${ }^{2}$, Chin-Hong Puah ${ }^{2}$ and Rayenda Khresna Brahmana ${ }^{2}$, Ronald \\ Hasudungan Sianturi ${ }^{1}$ \\ ${ }^{1}$ Faculty of Law, Universitas Prima Indonesia, 20113, Jalan Sekip Simpang Sikambing, Medan, North Sumatera, \\ Indonesia. \\ ${ }^{2}$ Faculty of Economics and Business, Universiti Malaysia Sarawak, \\ 94300 Kota Samarahan, Sarawak, Malaysia
}

\begin{abstract}
Indonesia is Malaysia's second tourist generating country after Singapore, therefore it is important to look at the macroeconomic determinants of Indonesia tourism demand in Malaysia in order to maintain and sustain the significant Indonesian tourist inflows into Malaysia. This study employed quarterly data from 2000Q1 to 2014Q4 to estimate Indonesian tourism demand with the explanatory variables of real income, travel cost and exchange rate. The empirical findings suggest that there is a long-run equilibrium relationship between Indonesian tourism demand and the specified determinants. In summary, higher Indonesian real income, higher travel cost and stronger Indonesian currency will encourage more Indonesian visitors visiting Malaysia.
\end{abstract}

\section{Introduction}

Malaysia, among the countries that have benefited from its tourism sector, has ranked at 26 in the world for benefiting from tourism sector total contribution to its Gross Domestic Products (GDP) in 2014 [World Travel and Tourism Council (WTTC), 2015]. After suffering from primary commodities price plunge and manufacturing industry fragility towards global economic crises, Malaysian government established the Ministry of Culture, Arts and Tourism in 1987 and the Ministry was renamed in 2004 as Ministry of Tourism with the vision of developing Malaysia as a world-class tourist destination. Various promotional campaigns were carried out under Ministry of Tourism which includes a series of Visit Malaysia Year in 1990, 1994, 2000, 2007 and 2014 as well as Malaysia Year of Festivals (MyFEST) in 2015.

WTTC has further highlighted the contribution of Malaysian tourism sector contribution towards its economy performance in its Economic Impact report 2015 in which tourism sector is reported to have contributed to RM 161.0 billion (14.9 percent of GDP) in 2014 and this figure is forecasted to increase to RM 262.2 billion (15.8 percent) in 2025. Moreover, Malaysian tourism sector has supported 13.0 percent $(1,770,000$ jobs $)$ of total employment in Malaysia for 2014. In 2025, this number is expected to incline to 14.4 percent $(2,489,000$ jobs $)$ of total employment. On the other hand, the importance of tourism sector can also be seen through Malaysian government's total investment in this sector. The Malaysian government has invested RM 19.4 billion in 2014 and WTTC projected that the amount of investment would increase to RM 37.7 billion in 2025.

${ }^{1}$ Malaysia tourism board reports that the largest inbound tourists for Malaysia are originated from Singapore with 50.78 percent of total tourists are Singaporean. Indonesia follow as the second tourist generating country with 10.31 percent, China ranked on the third with 5.88 percent, followed by Thailand (4.74 percent), Brunei (4.42 percent), India (2.81 percent), Philippines (2.25 percent), Australia (2.08 percent), Japan (2.02 percent) and lastly, countries around the globe cumulatively contributed 14.72 percent.

Therefore, Malaysian government can take precautionary action through the effort to try and diversify its sources of tourist arrival to avoid the overdependence on Singapore. Indonesia as Malaysia's neighbouring country is ranked second as its tourist generating country has the potential to replace Singapore as Malaysia's main tourist generating country in the case of Singapore's economy are facing a downturn. In this case, a study to examine the determinants of Indonesian tourism demand in Malaysia would provide informative insight to attract more inflows of Indonesian tourists.

\section{Literature Review}

Among the measurements widely used in the tourism demand study to represent tourism demand

\footnotetext{
${ }^{1}$ See http://mytourismdata.tourism.gov.my/ (January 07, 2016)
} 